\title{
Hubungan Paparan Sinar Matahari, Status Gizi, dan Asupan Makan terhadap Kadar Vitamin D Anak dan Remaja Penderita Diabetes Mellitus Tipe 1
}

\section{Sunlight Exposure, Nutritional Status, and Food Intake associated Vitamin D Level in Type 1 Diabetes Mellitus Children and Adolescents}

\author{
Inggita Kusumastuty ${ }^{1 *}$, Dian Handayani ${ }^{1}$, Harjoedi Adji Tjahjono ${ }^{2}$, Elsa Permata Sari ${ }^{1}$, Silvy Kartika Rahayuningtyas ${ }^{1}$, \\ Andanu Bima Saputra ${ }^{1}$
}

\begin{abstract}
ABSTRAK
Latar belakang : Penelitian terdahulu melaporkan bahwa penderita Diabetes Tipe 1 mengalami defisiensi vitamin D. Defisiensi vitamin D disebabkan karena kurangnya asupan vitamin D, paparan sinar matahari atau status gizi. Indonesia adalah negara tropis yang dekat dengan katulistiwa dengan sinar matahari sepanjang tahun. Penelitian kadar vitamin D pada anak dan remaja penderita Diabetes Tipe 1 masih belum banyak dilakukan di Indonesia.

Tujuan: menganalisis hubungan paparan sinar matahari, status gizi, asupan makan dengan kadar vitamin D pada anak dan remaja penderita Diabetes Tipe 1.

Metode: Desain penelitian ini adalah cross-sectional dengan jumlah sampel 31 anak dan remaja Diabetes Tipe 1 berusia 5-19 tahun. Pengumpulan data paparan sinar matahari dengan menggunakan form Sun Exposure Questionnaire, status gizi IMT/U dengan WHO Anthro, asupan makan dengan Semi - Quantitative Food Frequency Questioner dan kadar vitamin D dengan metode ELISA. Analisa statistik menggunakan SPSS Versi 21 dengan uji korelasi Pearson dan Spearman.

Hasil: Seluruh responden mengalami defisiensi vitamin D, sebagian besar responden memiliki paparan sinar matahari kurang dan status gizi dalam kategori normoweight. Mayoritas responden memiliki asupan energi dan protein baik, lemak berlebih, karbohidrat kurang, vitamin D dan kalsium kurang. Terdapat hubungan positif antara paparan sinar matahari dengan kadar vitamin $D(p=0.001, r=0.627)$. Namun tidak terdapat hubungan antara status gizi, asupan protein, lemak, karbohidrat, vitamin $D$ dan kalsium dengan kadar vitamin $D(p=0.409 ; p=0.240 ; p=0.311 ; p=0.822 ; p=0.231 ; 0.382)$

Kesimpulan: Semakin banyak paparan sinar matahari maka semakin tinggi kadar vitamin $D$, akan tetapi tidak ada hubungan antara status gizi dan asupan makan dengan kadar vitamin D pada anak dan remaja DM tipe 1.
\end{abstract}

Kata Kunci: Diabetes Mellitus Tipe 1, Paparan Sinar Matahari, Status Gizi, Intake Makan, Kadar Vitamin D

\section{ABSTRACT}

Background: Previous research state the correlation between vitamin D deficiency and Type 1 diabetes. The deficiency of Vitamin $D$ is caused by deficiency of vitamin D intake, sunlight exposure, or nutritional status. Indonesia, as a tropical country, is close to the equator and receives sunlight all year long. Little research has been done on vitamin $D$ levels in children and adolescents with Type 1 Diabetes in Indonesia.

Objective: The study aims to determine the relationship among sunlight exposure, nutritional status, food intake, and vitamin $D$ levels in children and adolescents with Type 1 Diabetes.

Methods: The study design was cross-sectional with a sample size of 31 children and adolescents with Type 1 Diabetes aged 519 years. Sunlight exposure data were collected using the Sun Exposure Questionnaire form, nutritional status o BMI/age data were using the WHO Anthro, food intake data were using the Semi-Quantitative Food Frequency Questioner, and vitamin D level data were using the ELISA method. Statistical analysis was conducted by using SPSS Version 21 with Pearson and Spearman correlation test.

Results: All respondents showed vitamin D deficiency. Most respondents had low sunlight exposure and nutritional status in the normoweight category. The majority of respondents had good energy and protein intake, excess fat, low carbohydrates, and low vitamin $D$ and calcium. There is a positive relationship between sunlight exposure and vitamin $D$ level $(p=0.001, r=$ $0.627)$. However, there is no relationship among nutritional status, protein intake, fat, carbohydrates, vitamin $D$ and calcium on the level of vitamin $D(p=0.409 ; p=0.240 ; p=0.311 ; p=0.822 ; p=0.231 ; 0.382)$.

Conclusion: The more sun exposure, the higher the level of vitamin $D$, but there is no relationship between nutritional status and food intake with vitamin D levels in children and adolescents with Type 1 Diabetes.

Keywords: Type 1 Diabetes Mellitus, Sunlight Exposure, Nutritional Status, Food Intake, Vitamin D Level 
*Korespondensi::
inggita@ub.ac.id*
Inggita Kusumastuty*
1Jurusan Gizi Fakultas Kedokteran Universitas Brawijaya, Indonesia
'Laboratorium Ilmu Kesehatan Anak Rumah Sakit Umum Daerah Dr. Saiful Anwar Malang, Indonesia

\section{PENDAHULUAN}

Diabetes Mellitus Tipe 1 (DM Tipe 1) merupakan penyakit gangguan endokrin paling umum terjadi pada anak dan remaja di seluruh dunia yang insidennya meningkat beberapa dekade terakhir ${ }^{1}$. Pada tahun 2017, terdapat 132.600 insiden DM Tipe 1 dengan jumlah penderita diseluruh dunia diperkirakan lebih dari satu juta, terbanyak di Eropa dan di North American \& Caribbean (28,4\% dan 21,5\%), di Asia Tenggara terdapat 150.000 orang penderita (13,5\%). Di Indonesia insiden DM Tipe 1 adalah 0,7 tiap 100.000 anak dan jumlah kejadian DM Tipe 1 pada usia 0-19 tahun meningkat sebesar 443\% dari 1021 kasus pada tahun 2015 menjadi 4532 kasus pada tahun $2017^{2,3}$.

Pada pasien DM Tipe 1 ditemukan kondisi rendahnya kadar vitamin D. Suatu penelitian meta analisis pada tahun 2014 menyebutkan bahwa kadar 25hidroxyvitamin $\mathrm{D}$ anak dengan DM Tipe 1 lebih rendah dibandingkan dengan anak yang sehat ${ }^{4}$. Penelitian terhadap 117 anak dan remaja penderita DM Tipe 1 di Saudi Arabia sebanyak 59,9\% memiliki kadar 25 hidroxyvitamin D dalam darah yang rendah ${ }^{5}$. Rendahnya kadar vitamin D yang terjadi pada anak DM Tipe 1 dapat berpengaruh pada perkembangan komplikasi diabetes. Efek angiogenik dan efek inflamasi akibat defisiensi vitamin $D$ diketahui dapat meningkatkan prevalensi retinopati pada DM Tipe $1^{6}$. Suatu penelitian kohort selama 16 tahun follow up, melaporkan rendahnya kadar vitamin $\mathrm{D}$ pada pasien DM Tipe 1 berhubungan dengan microalbuminuria7.

Rendahnya kadar vitamin D dapat disebabkan karena multifaktor diantaranya asupan makanan sumber vitamin D tidak adekuat, paparan terhadap sinar matahari tidak adekuat, atau malabsorbsi lemak ${ }^{8}$. Paparan sinar matahari menentukan produksi vitamin $D$ karena vitamin D dapat disintesis oleh kulit dengan bantuan radiasi Ultraviolet B yang diperoleh saat terpapar sinar matahari9. Penelitian terdahulu menyebutkan bahwa paparan sinar matahari mempunyai hubungan positif dengan kadar 25(OH)D. Penelitian terhadap 331 anak dan remaja berusia 6-17 tahun di Arab Saudi melaporkan hubungan positif antara paparan sinar matahari dengan kadar $25(\mathrm{OH}) \mathrm{D}^{10}$.

Tersedianya paparan sinar matahari yang cukup memungkinkan produksi vitamin $D$ yang memadai. Radiasi ultraviolet B yang lebih kuat terdapat di daerah dekat garis khatulistiwa ${ }^{11}$. Negara Indonesia berada pada kawasan katulistiwa antara $6^{\circ} \mathrm{LU}-11^{\circ} \mathrm{LS}$ dan dari $95^{\circ} \mathrm{BT}-$ $141^{\circ} \mathrm{BT}$. Karena terletak pada daerah katulistiwa, wilayah Indonesia banyak menerima sinar matahari dengan sinar matahari terjadi sepanjang tahun ${ }^{12}$. Dengan melimpahnya sinar matahari di wilayah Indonesia sebagai sumber utama vitamin D diharapkan kadar vitamin D pada anak dan remaja khususnya penderita DM Tipe 1 dapat berada pada rentang normal dan tidak mengalami defisiensi.

Peningkatan adiposit diketahui juga berkorelasi dengan rendahnya kadar vitamin $D^{13}$. Hal tersebut terjadi karena adiposa merupakan tempat penyimpanan untuk zat-zat yang bersifat lipofilik ${ }^{14}$. Peningkatan jumlah dan ukuran adiposit disebut juga dengan obesitas. Beberapa hasil penelitian melaporkan bahwa anak-anak yang mengalami obesitas memiliki kadar vitamin $D$ yang rendah ${ }^{15}$. Penelitian meta analisis pada tahun 2014 juga melaporkan bahwa prevalensi defisiensi kadar vitamin D lebih tinggi pada subjek yang obesitas ${ }^{16}$.

Kadar vitamin D pada anak DM Tipe 1 di Indonesia masih jarang dilakukan penelitian. Penelitian ini bertujuan untuk mengetahui hubungan antara paparan sinar matahari, status gizi dan asupan makan dengan kadar vitamin D pada anak dan remaja Diabetes Mellitus Tipe 1.

\section{METODE}

Subjek Penelitian

Penelitian analitik observasional dengan pendekatan cross-sectional ini dilakukan selama periode Desember 2018 sampai dengan Maret 2019 setelah mendapat persetujuan dari Komite Etik Rumah Sakit Saiful Anwar Malang Nomor: 400/214/K.3/302/2018. Jumlah sampel 31 orang ditentukan berdasarkan rumus perhitungan jumlah sampel untuk penelitian analisis korelatif ${ }^{17}$. Pengambilan sampel dilakukan secara purposive sampling berdasarkan kriteria inklusi dan eksklusi. Kriteria inklusi dalam penelitian ini adalah pasien rawat jalan DM Tipe 1 di Kota Malang dan bersedia menjadi subyek penelitian. Peserta penelitian di eksklusi jika mengalami kondisi sebagai berikut: gangguan fungsi ginjal, gangguan fungsi hati, malabsorbsi lemak (ditandai dengan warna feses terang, sangat bau dan mengapung saat buang air besar), mengkonsumsi suplemen vitamin $D$, dan mengkonsumsi obat yang mempengaruhi metabolisme vitamin $D$ seperti penggunaan obat secara rutin jenis kortikosteroid dan orlistat (obat penurun berat badan).

\section{Pengumpulan Data}

Pengumpulan data dilakukan setelah responden menyetujui dan menandatangani informed consent. Data paparan sinar matahari dikumpulkan dengan meminta responden melakukan pengisian formulir pencatatan harian aktifitas di luar ruangan selama tujuh hari. Setelah responden melakukan pencatatan/self report dan mengirimkan formulir tersebut melalui kantor pos maka peneliti melakukan rekapitulasi ke form SEQ (Sun Exposure Questionnaire) ${ }^{18}$.

Data status gizi berupa berat badan dan tinggi badan dilakukan oleh enumerator terlatih dengan latar belakang pendidikan DIII Gizi dan telah melakukan standarisasi. Berat badan ditimbang menggunakan 
timbangan injak digital merk Omron dengan tingkat ketelitian $0,1 \mathrm{~kg}$ dan tinggi badan diukur menggunakan microtoise merk Seca dengan tingkat ketelitian $0,1 \mathrm{~cm}$. Status gizi dikategorikan berdasar Z-Score IMT menurut Umur (standar WHO 2006) untuk anak dan remaja usia 019 tahun.

Data asupan makan diperoleh dengan cara wawancara menggunakan form Semi - Quantitative Food Frequency Questioner (SQ-FFQ), food model dan food picture. Data asupan yang didapat dari wawancara diolah menggunakan aplikasi Nutrisurvey 2007. Data asupan makan disajikan dalam bentuk pemenuhan asupan dan distribusi asupan berdasarkan kategori. Pemenuhan asupan merupakan perhitungan dari asupan dibandingkan kebutuhan, sedangkan distribusi ditetapkan berdasarkan kategori tingkat asupan. Persentase Asupan energi dan zat gizi makro sebesar 80$110 \%$ dikatakan baik, persentase asupan $<80 \%$ dikatakan kurang dan persentase asupan $>110 \%$ dikatakan berlebih ${ }^{19}$. Sedangkan asupan zat gizi mikro dibandingkan dengan Angka Kecukupan Gizi Tahun 201320. Dikatakan kurang jika asupan lebih rendah dari AKG dan dikatakan baik jika asupan sesuai atau melebihi AKG.

Data kadar vitamin D diukur menggunakan plasma dengan metode Enzyme-linked Immune Assay (ELISA) menggunakan kit Alegria Human Vit D. Sedangkan data karakteristik umum responden didapatkan dengan melakukan wawancara.

Analisis Data

Analisa statistik dilakukan menggunakan SPSS Versi 21.0. Analisa univariat dilakukan untuk masingmasing variabel baik independen maupun dependen.
Analisis bivariat dilakukan untuk melihat hubungan paparan sinar matahari, status gizi dan asupan makan dengan kadar vitamin D. Sebelum dilakukan analisis bivariat untuk data numerik dilakukan Uji Shapiro Wilk untuk melihat apakah data terdistribusi normal atau tidak.

Hubungan antara variabel paparan sinar matahari, asupan makan dengan kadar vitamin $D$ akan dilakukan uji korelasi pearson untuk melihat hubungan antara status gizi dan kadar vitamin D dilakukan uji korelasi spearman. Terdapat korelasi yang bermakna antara variabel independen dan dependen jika $p$ value $<$ 0.05 .

\section{HASIL DAN PEMBAHASAN}

Karakteristik responden dapat dilihat pada Tabel 1. Berdasarkan hasil penelitian, sebagian besar responden berjenis kelamin perempuan (67.7\%) dan terbanyak di usia > 12-19 tahun dengan usia rata-rata 13.6 tahun. Hal ini sesuai dengan epidemiologi Diabetes Tipe 1 bahwa puncak kejadian adalah saat usia 5-7 tahun dan saat usia 12-14 tahun atau pubertas ${ }^{21}$. Responden perempuan ditemukan lebih banyak dibandingkan dengan laki-laki didukung oleh penelitian di Saudi Arabia bahwa sebagian besar dari 117 anak dan remaja penderita Diabetes Tipe 1 adalah perempuan (55.6\%). Sebaliknya, berdasarkan systematic review terhadap 54 penelitian tentang insiden terjadinya Diabetes Tipe 1 menyebutkan bahwa laki-laki 1,47 kali lebih banyak mengalami Diabetes Tipe 1 dibanding perempuan ${ }^{22}$. Perbedaan ini dapat disebabkan karena populasi, ras, serta subjek penelitian yang beragam ${ }^{23}$

Tabel 1. Distribusi Data Responden

\begin{tabular}{|c|c|c|}
\hline Karakteristik & $\mathbf{N}$ & $\%$ \\
\hline \multicolumn{3}{|l|}{ Jenis Kelamin } \\
\hline Laki-laki & 10 & 32.3 \\
\hline Perempuan & 21 & 67.7 \\
\hline \multicolumn{3}{|l|}{ Usia (tahun) } \\
\hline \multicolumn{3}{|l|}{ Kategori usia : } \\
\hline $5-12$ & 13 & 41.9 \\
\hline$>12-19$ & 18 & 58.1 \\
\hline \multicolumn{3}{|l|}{ Penggunaan sunscreen } \\
\hline Ya & 12 & 38.7 \\
\hline Tidak & 19 & 61.3 \\
\hline \multicolumn{3}{|l|}{ Klasifikasi Vitamin D } \\
\hline Defisiensi & 31 & 100 \\
\hline Insufisiensi & 0 & 0 \\
\hline Normal & 0 & 0 \\
\hline \multicolumn{3}{|l|}{ Status Gizi } \\
\hline Kurang & 4 & 13 \\
\hline Normal & 23 & 74 \\
\hline Berlebih & 2 & 6.5 \\
\hline Obesitas & 2 & 6.5 \\
\hline
\end{tabular}

Kategori status vitamin $\mathrm{D}$ responden dapat dilihat pada Tabel 1. Rata-rata kadar vitamin D responden adalah $9.4 \mathrm{ng} / \mathrm{mL}$. Kadar vitamin D dikatakan defisiensi jika $\leq 20$ $\mathrm{ng} / \mathrm{mL}$. Penelitian ini menunjukkan seluruh responden memiliki kadar vitamin $\mathrm{D}<20 \mathrm{ng} / \mathrm{mL}$. Hasil analisis menggunakan uji korelasi Pearson menunjukkan bahwa terdapat korelasi negatif bermakna antara usia dengan kadar vitamin $D(p$ value $=0.028, r=-0.395)$. Korelasi negatif berarti semakin tinggi umur maka kadar vitamin $D$ akan semakin rendah atau menurun. Hasil serupa juga 
dilaporkan oleh Dix et al. bahwa terdapat korelasi yang signifikan antara kadar 25(OH)D serum dengan usia responden ${ }^{24}$. Hal tersebut dapat dijelaskan berdasarkan teori bahwa seiring bertambahnya usia, 7dehydrocholestrol di lapisan epidermis kulit sebagai bahan dasar sintesis endogen vitamin D akan mengalami penurunan. Penelitian yang membandingkan kadar vitamin D pada orang dewasa yang berusia 20-30 tahun dengan yang berusia 62-80 tahun yang diberikan paparan UVB buatan, ditemukan hasil vitamin $D$ yang diproduksi oleh orang dewasa berusia 20-30 tahun tiga kali lipat lebih banyak $^{25}$.

Faktor lainnya yang dapat mempengaruhi kadar vitamin $D$ adalah penggunaan sunscreen atau krim pelindung kulit dari sinar matahari. Berdasarkan hasil penelitian didapatkan hasil bahwa sebagian besar responden tidak menggunaan sunscreen yaitu sebanyak 19 orang $(61.3 \%)$. Berdasarkan hasil analisis terdapat korelasi yang tidak signifikan antara penggunaan sunscreen dengan kadar vitamin $D$ responden ( $p$ value $=$ 0.339). Hal ini didukung oleh penelitian metaanalisis yang melihat perilaku sun protective pada populasi Amerika yang melaporkan bahwa tidak terdapat korelasi

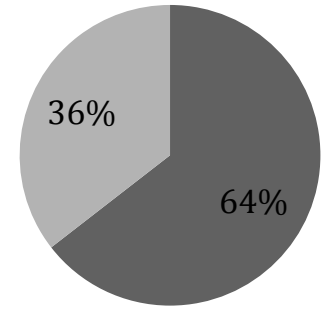

(1a.) penggunaan sunscreen dengan kadar vitamin $\mathrm{D}^{26}$. Hasil penelitian ini juga sesuai dengan teori bahwa penggunaan sunscreen pada anak-anak, remaja, dan dewasa muda hanya sedikit kemungkinan untuk berhubungan dengan kadar vitamin $\mathrm{D}$ karena tidak menggunakan sunscreen sesuai jumlah dan waktu yang direkomendasikan, lain hal nya dengan individu dewasa yang menggunakan sunscreen untuk penampilan dan kesehatan sehingga lebih rutin dalam menggunakan ${ }^{27}$.

Penelitian ini menunjukkan median total skor paparan sinar matahari responden adalah 14 dengan skor terendah 7 dan tertinggi 34. Berdasarkan total skor paparan sinar matahari diketahui bahwa sebagian besar responden memiliki paparan sinar matahari yang kurang (64.5\%) dan hanya sebagian kecil saja yang memiliki paparan sinar matahari yang cukup, yaitu berjumlah 11 orang (35.5\%) (Gambar 1a). Selain total skor paparan sinar matahari, juga dapat dilihat skor waktu (The weekly sun score: Time) dan skor bagian kulit yang terpapar sinar matahari (The weekly sun score: Skin Exposure). Tidak sampai setengah dari responden yang memiliki waktu dan bagian kulit terpapar sinar matahari yang cukup (45.0\%) (Gambar 1b dan 1c).

\section{- Kurang (sMedian) $\quad$ Cukup (>Median)}

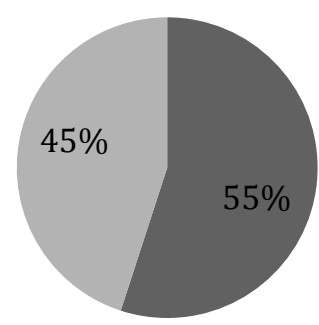

(1b.)
- Kurang ( $\leq$ Median) $\quad$ Cukup (>Median)

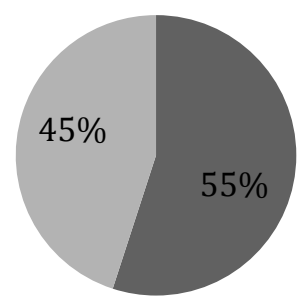

(1c.)

Gambar 1. Distribusi Frekuensi Paparan Sinar Matahari

Berdasarkan hasil analisis dengan uji korelasi Pearson terdapat korelasi positif bermakna antara paparan sinar matahari (total skor) dengan kadar vitamin $D(p$ value $=0.001, r=0.627)$. Hal ini menunjukkan bahwa semakin tinggi atau semakin banyak paparan sinar

\section{Keterangan}

1a. : Distribusi Frekuensi Anak dan Remaja Penderita DM Tipe 1 berdasarkan Total Skor Paparan Sinar Matahari

1b. : Distribusi Frekuensi Anak dan Remaja Penderita DM Tipe 1 berdasarkan Bagian Kulit yang Terpapar Sinar Matahari

1c. : Distribusi Frekuensi Anak dan Remaja Penderita DM Tipe 1 berdasarkan Waktu Terpapar Sinar Matahari

matahari maka akan semakin tinggi kadar vitamin D. Begitu juga antara skor bagian kulit dan kadar vitamin D ditemukan korelasi positif yang signifikan ( $p$ value $=0.006$, $r=0.485$ ) yang menunjukkan bahwa semakin banyak bagian kulit yang terpapar sinar matahari maka kadar 
vitamin D akan semakin tinggi. Sedangkan antara skor waktu dan kadar vitamin $\mathrm{D}$ tidak ditemukan korelasi yang bermakna, namun berdasarkan arah korelasi ditemukan arah korelasi positif yang menunjukkan trend bahwa semakin lama waktu terpapar terhadap sinar matahari akan semakin tinggi kadar vitamin $D(p$ value $=0.099, r=$

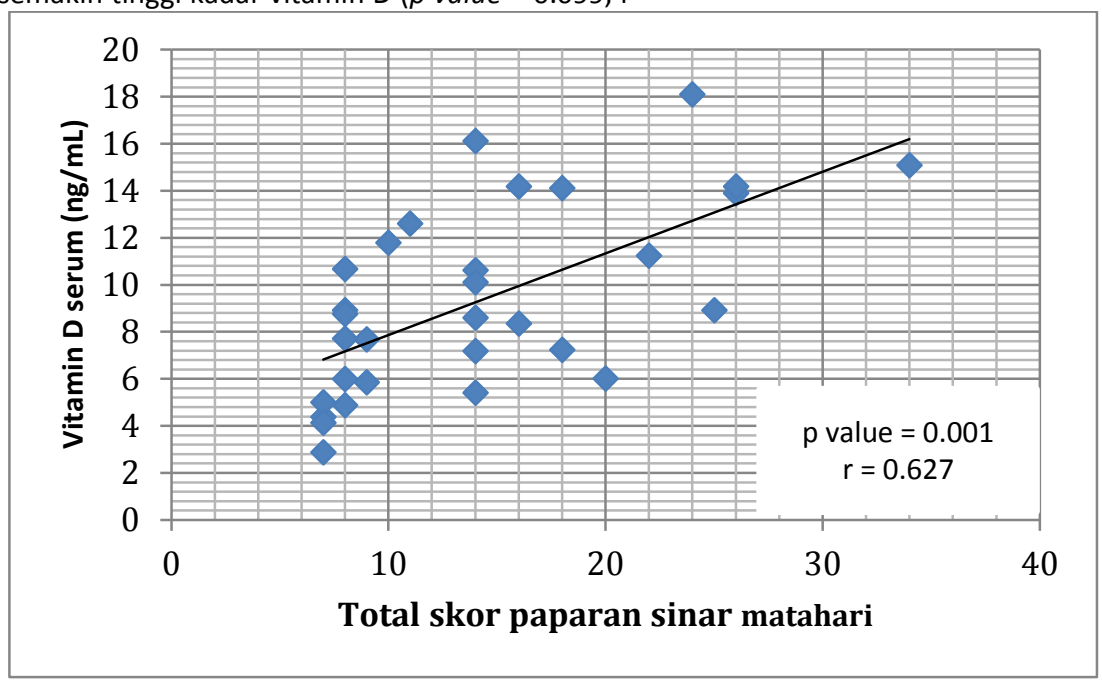

(a)

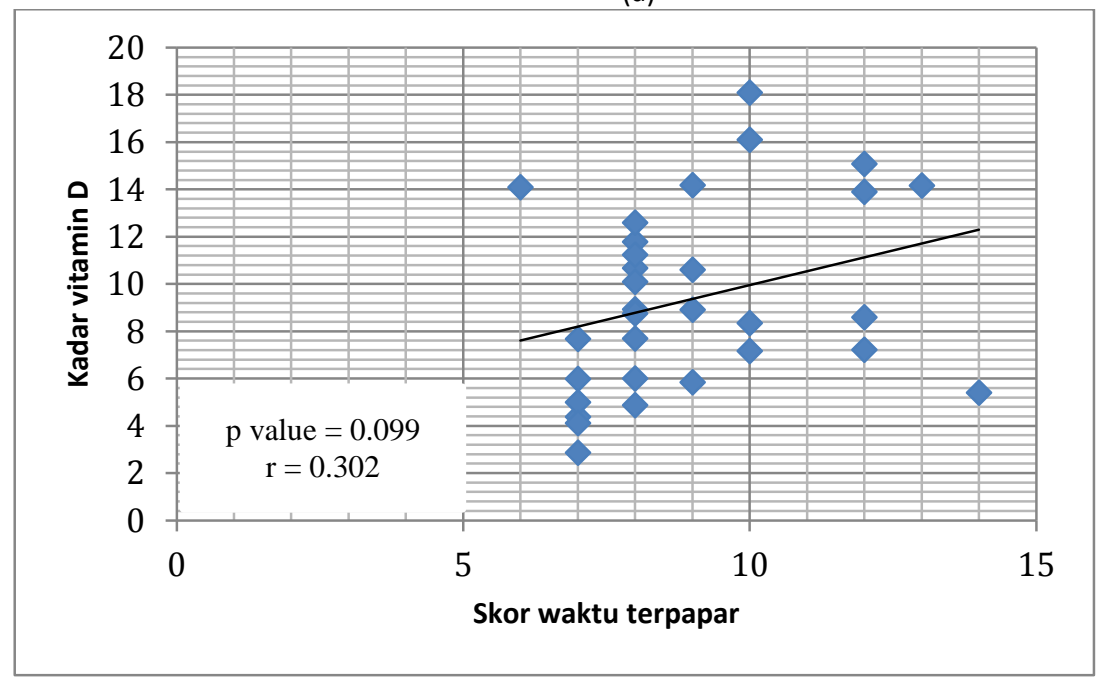

(b)

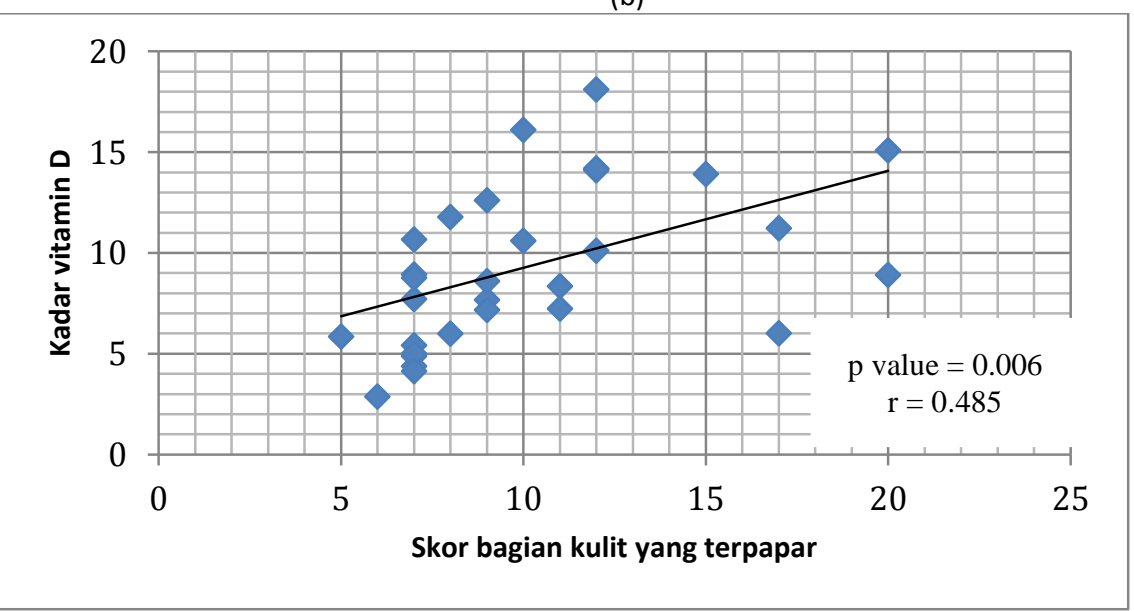

(c)

Gambat 2. Analisis Paparan Sinar Matahari dari Kadar Vitamin D
0.302). Hubungan antara paparan sinar matahari dan kadar vitamin D dapat dilihat pada Gambar 2 (a),(b),(c)

\section{Keterangan:}

2a. Hubungan paparan Sinar Matahari dan Kadar Vitamin D

2b. Hubungan Waktu Terpapar Sinar Matahari (Time) dengan Kadar Vitamin

2c. Hubungan Bagian Kulit yang Terpapar Sinar Matahari (Skin Exposure) dengan Kadar Vitamin D 
Pada penelitian ini ditemukan seluruh responden (100\%) memiliki kadar vitamin D dengan kategori defisiensi ( $\leq 20 \mathrm{ng} / \mathrm{mL}$ ). Penelitian ini meneliti paparan sinar matahari responden namun tidak melihat asupan makanan sumber vitamin $D$ responden. Paparan sinar matahari responden didapatkan berupa total skor paparan selama seminggu berupa hasil perkalian antara lama terpapar dan bagian kulit yang terpapar.

Berdasarkan hasil kuisioner didapatkan bahwa paparan sinar matahari responden sebagian besar tergolong kurang $(64.5 \%$ responden memiliki total skor paparan sinar matahari) yang kurang dari median, dimana kebanyakan responden setiap hari terpapar sinar matahari kurang dari 30 menit dan bahkan ada yang kurang dari 5 menit dan bagian tubuh yang terpapar pada umumnya hanya tangan dan wajah saja. Kurangnya paparan sinar matahari pada responden diakibatkan karena sebagian besar responden menghabiskan waktu untuk beraktifitas di dalam ruangan. Namun terdapat beberapa responden yang memiliki total skor paparan sinar matahari lebih dari median yaitu sebanyak 11 orang, hal ini disebabkan responden tersebut terpapar sinar matahari dalam waktu yang lebih lama yaitu lebih dari 30 menit dan atau bagian tubuh yang terpapar lebih luas meliputi tangan, wajah, lengan, dan tungkai.

Peneliti menggunakan pendekatan crosssectional dan melakukan uji statistik bivariat untuk melihat ada atau tidak korelasi antara paparan sinar matahari dan kadar vitamin D. Hasilnya adalah terdapat korelasi yang signifikan antara total skor paparan sinar matahari terhadap kadar vitamin $D$ dengan nilai $p=0.001$ $(p<0,05)$, terdapat korelasi yang signifikan antara skor bagian kulit yang terpapar terhadap kadar vitamin $D$ dengan nilai $p=0.006(p<0,05)$, dan tidak terdapat korelasi yang signifikan antara skor waktu terpapar sinar matahari namun menunjukkan tren positif dengan nilai $r$ $=0.302$. Hal ini sejalan dengan penelitian di India yang meneliti pengaruh paparan sinar matahari pada bayi selama 6 bulan pertama setelah lahir dengan kadar vitamin D. Pada penelitian tersebut berdasarkan uji korelasi Pearson diketahui bahwa terdapat korelasi positif yang signifikan antara paparan sinar matahari dengan kadar vitamin $D$ dengan nilai $p=0.003(p<0.05)$. Penelitian tersebut juga menyatakan bahwa minimal 30 menit paparan terhadap sinar matahari antara pukul 10 pagi dan pukul 3 sore yang mengenai $40 \%$ bagian tubuh bayi selama 16 minggu akan menjadikan kadar vitamin $D$ pada kondisi yang sufisien ${ }^{28}$.

Penelitian lain yang mendukung adalah hasil penelitian tentang faktor-faktor yang mempengaruhi defisiensi vitamin D pada anak Diabetes Tipe 1 berusia 818 tahun di Iran. Pada penelitian tersebut diketahui bahwa terdapat hubungan antara paparan sinar matahari dengan kadar vitamin $D$ dengan nilai $p<0.001$. Selain meneliti tentang paparan sinar matahari penelitian ini juga meneliti tentang Indeks Massa Tubuh (IMT) serta aktifitas fisik dan hubungannya dengan kadar vitamin $D$ (25(OH)D). Penelitian yang dilakukan oleh Saki et al. ini mempunyai kemiripan dengan penelitian yang dilakukan oleh peneliti dalam hal rancangan penelitian yaitu sama- sama menggunakan rancangan cross-sectional serta paparan sinar matahari yang mempertimbangkan lama waktu terpapar yaitu < 15 menit/hari, 15-30 menit/hari dan $>30$ menit/hari29.

Sebaliknya, penelitian lain melaporkan hasil yang berlawanan dengan penelitian ini bahwa tidak terdapat hubungan yang signifikan antara paparan sinar matahari, pengukuran antropometri, dan lama menderita Diabetes Tipe 1. Meskipun penelitian yang dilakukan oleh Hassan ini sama-sama dilakukan terhadap responden dengan jumlah sama \pm 30 orang, namun terdapat perbedaaan dalam instrumen yang digunakan dalam mendapatkan data paparan sinar matahari, dimana pada penelitian ini hanya melihat lama waktu terpapar sinar matahari perhari tanpa mempertimbangkan bagian kulit yang terpapar, selain itu Kit yang digunakan dalam menentukan kadar vitamin $\mathrm{D}$ responden juga berbeda ${ }^{30}$.

Paparan sinar matahari memberikan kontribusi 90-95\% kebutuhan vitamin D manusia. Paparan sinar matahari dalam sinar ultra violet (spectrum 280-320 UVB) memberikan peran yang besar dalam membantu sintesis vitamin D3 (3000 IU) di kulit. Sinar ultraviolet yang mengenai permukaan kulit akan merubah 7dehydrocholesterol (7-DHC) menjadi pra vitamin D3 dan kemudian diisomerisasi termal menjadi vitamin D3 atau kolekalsiferol ${ }^{28}$.

Responden sebagian besar pada penelitian ini memiliki status gizi normal (74.2\%), dan hanya sebagian kecil responden yang memiliki status gizi tidak normal (BB lebih maupun BB kurang) (Tabel 1). Penelitian di Brazil terhadap 195 anak dan remaja Diabetes Tipe 1 oleh da Costa et al (2016) juga menunjukkan terdapat 59\% anak dan remaja dengan status gizi normal, $1 \%$ dengan gizi kurang, dan 40\% dengan gizi lebih (overweight dan obesitas). Berdasarkan hasil analisis korelasi ditemukan tidak terdapat hubungan yang signifikan antara status gizi dengan kadar vitamin $D(p=0.409$, spearman). Hal ini sejalan dengan penelitian yang dilakukan di Iran yang meneliti hubungan antara Indeks Massa Tubuh dan kadar vitamin D pada anak usia 8-18 tahun penderita Diabetes Tipe 1. Pada penelitian tersebut diketahui bahwa tidak terdapat korelasi yang signifikan antara Indeks Massa Tubuh dengan kadar vitamin $D$ dengan nilai $p=0.91(p>$ 0.05) [27]. Penelitian lainnya dengan hasil yang sama adalah penelitian di Chili Santiago terhadap 30 penderita Diabetes Tipe 1. Pada penelitian tersebut diketahui bahwa tidak terdapat hubungan antara status gizi berdasarkan IMT dengan kadar vitamin $D$ dengan nilai $p$ $=0.212(p>0.05)^{31}$.

Penelitian lainnya melaporkan hasil yang berlawanan dengan hasil yang diperoleh peneliti. Dalam penelitian tersebut dilaporkan terdapat korelasi antara status gizi berdasarkan Indeks Massa Tubuh dengan kadar vitamin $D$ dengan nilai $p=0.001(p<0.05)^{16}$. Suatu penelitian metaanalisis juga melaporkan bahwa setiap kenaikan $1 \mathrm{~kg} / \mathrm{m}^{2} \mathrm{IMT}$ berhubungan dengan penurunan $1.15 \%$ kadar $25(\mathrm{OH}) \mathrm{D}$ dengan nilai $\mathrm{p}$ value $=6.25 \times 10^{-27}$ $(p<0.05)^{32}$. Dua penelitian diatas memiliki perbedaan dengan yang dilakukan peneliti yaitu subjek penelitian yang digunakan tidak pada anak dan remaja yang 
mengalami Diabetes Tipe 1 namun pada responden yang berusia $>18$ tahun sehingga hal tersebut berkemungkinan menyebabkan hasil yang berbeda, selain itu jumlah responden yang digunakan juga lebih banyak. Status gizi khususnya obesitas merupakan faktor yang dapat mempengaruhi kadar vitamin $D$ didalam tubuh karena obesitas berkaitan dengan tingginya kadar lemak di dalam tubuh. Berdasarkan teori semakin tinggi lemak tubuh maka kadar vitamin D akan semakin rendah karena vitamin $D$ adalah vitamin larut lemak yang akan mengalami penumpukan di jaringan adipose ${ }^{33}$. Namun, berdasarkan hasil analisis tidak terdapat korelasi yang signifikan antara status gizi berdasarkan indeks massa tubuh karena selain responden penelitian lebih banyak memiliki status gizi normal juga diperlukan pengukuran lemak tubuh dengan metode lain tidak dengan menggunakan Indeks Massa Tubuh.
Rata-rata pemenuhan asupan energi responden adalah $82.95 \%$, pemenuhan asupan protein $75.13 \%$, pemenuhan asupan lemak $116.48 \%$ dan pemenuhan asupan karbohidrat $66.90 \%$ (Tabel 2). Mayoritas responden memiliki asupan energi dan protein baik, asupan lemak berlebih dan asupan karbohidrat kurang (Tabel 4). Hasil penelitian menunjukkan bahwa seluruh responden memiliki asupan vitamin D kurang dari Angka Kecukupan Gizi (AKG). Rata-rata asupan vitamin D responden hanya mencapai $25.87 \%$ dari anjuran AKG. Demikian pula pada asupan kalsium responden, mayoritas responden (96.6\%) memiliki asupan kalsium yang kurang. Rata-rata asupan kalsium responden adalah $449.92 \mathrm{mg} /$ hari (Tabel 5). Hasil penelitian menunjukkan tidak terdapat korelasi bermakna antara asupan makan (protein, lemak, karbohidrat, vitamin D dan kalsium) dengan kadar vitamin $\mathrm{D}$ responden (Table 3.)

Tabel 2. Gambaran Rata-rata Asupan dan Pemenuhan Energi dan Zat Gizi Makro dan Mikro

\begin{tabular}{lccc}
\hline \multicolumn{1}{c}{ Intake makan } & Nilai Mean \pm SD & Nilai Median & Nilai Minimal;Maximal \\
\hline Energi & $1509.59 \pm 419.7$ & & \\
asupan (g) & $82.95 \pm 29.74$ & 1460.5 & $814 ; 1674.4$ \\
pemenuhan (\%) & $68.28 \pm 25.4$ & 84.62 & $39.12 ; 152.76$ \\
Protein & $75.13 \pm 34.36$ & 62.25 & \\
asupan (g) & & 67.38 & $33.0 ; 106.6$ \\
pemenuhan (\%) & $70.26 \pm 25.9$ & 68.5 & $32.21 ; 181.64$ \\
Lemak & $116.48 \pm 49.4$ & 116.96 & $31.3 ; 79.5$ \\
asupan (g) & $154.16 \pm 52.5$ & & $40.45 ; 228.16$ \\
pemenuhan (\%) & $66.90 \pm 27.52$ & 145.7 & $70.8 ; 129.1$ \\
Karbohidrat & & 59.16 & $33.55 ; 177.71$ \\
$\begin{array}{l}\text { asupan (g) } \\
\text { pemenuhan (\%) }\end{array}$ & $2.28 \pm 1.6$ & 1.8 & \\
Vitamin D & & & $0.20 ; 8.0$ \\
$\begin{array}{l}\text { Asupan }(\mu \mathrm{g}) \\
\text { Kalsium }\end{array}$ & $449.92 \pm 247.98$ & 429.75 & $76.60 ; 1522.30$ \\
Asupan $(\mathrm{mg})$ & & & \\
\hline
\end{tabular}

Tabel 3. Distribusi Asupan Energi dan Zat Gizi Makro

\begin{tabular}{lccc}
\hline \multirow{2}{*}{ Energi dan Zat Gizi } & \multicolumn{3}{c}{ Kategori } \\
\cline { 2 - 4 } & Kurang & Baik & Lebih \\
\hline Energi (\%) & 37 & 47 & 16 \\
Protein (\%) & 22 & 55 & 23 \\
Lemak (\%) & 0 & 25 & 75 \\
Karbohidrat (\%) & 78 & 13 & 9 \\
\end{tabular}

Tabel 4. Hubungan Asupan Makan dengan Kadar Vitamin D

\begin{tabular}{cc}
\hline Variabel & Nilai p (uji korelasi Pearson) \\
\hline Protein & 0.240 \\
Lemak & 0.311 \\
Karbohidrat & 0.822 \\
Vitamin D & 0.231 \\
Kalsium & 0.382 \\
\hline
\end{tabular}

Tabel 5. Gambaran Asupan Zat Gizi Mikro

\begin{tabular}{lccc}
\hline \multicolumn{1}{c}{ Asupan } & Nilai Mean \pm SD & Nilai Median & Nilai Minimal;Maximal \\
\hline Vitamin D $(\mu \mathrm{g})$ & $2.28 \pm 1.6$ & 1.8 & $(0.20 ; 8.0)$ \\
Kalsium $(\mathrm{mg})$ & $449.92 \pm 247.98$ & 429.75 & $(76.60 ; 1522.30)$ \\
\hline
\end{tabular}


Berdasarkan hasil analisis korelasi pearson ditemukan tidak ada hubungan yang signifikan antara asupan protein, lemak dan karbohidrat dengan kadar vitamin $D(p=0.186, p=0.311, p=0.822)$. Hal ini bisa dilihat dari hasil penelitian bahwa rerata asupan makronutrien responden tidak sesuai rekomendasi. Hasil penelitian ini sejalan dengan penelitian Mazahery (2015) yang dilakukan di New-Zealand tentang faktor-faktor yang mempengaruhi konsentrasi 25(OH)D. Pada penelitian tersebut diketahui bahwa efek dari beberapa faktor demografis, penuaan, indeks massa tubuh (IMT) / persentase lemak tubuh, etnis, asupan kalsium, genetika, penggunaan estrogen, kandungan lemak dan komposisi lemak, dan beberapa penyakit dan obat. Lebih jauh lagi, seperti tindakan medis (jenis, dosis dan durasi suplementasi vitamin D) dan lingkungan (musim) adalah faktor lain yang berkontribusi ${ }^{34}$.

Analisis hasil penelitian ditemukan $62.5 \%$ responden pasien DM tipe 1 asupan total energinya tidak sesuai rekomendasi, asupan protein kurang dari rekomendasi (<20\% dari total energi), asupan karbohidrat kurang dari rekomendasi ( $<40 \%$ dari total energi) namun asupan lemak lebih dari rekomendasi $(>35 \%$ dari total energi). Asupan karbohidrat kurang $(<40 \%)$ berdampak pada sumber energi yang digunakan tubuh akan diperoleh dari sumber selain karbohidrat seperti protein dan lemak ${ }^{35}$. Ketika lemak dimetabolisme menjadi energi akan mengakibatkan penumpukan oksidatif asam lemak dan ketika protein dimetabolisme menjadi sumber energi maka akan mempengaruhi proses imunitas dan regenerasi sel ${ }^{36}$. Penumpukan oksidatif asam lemak akan meningkatkan resiko komplikasi terkait atherosclerosis dan kardiovaskular. Hasil penelitian ini menunjukkan bahwa tidak terdapat korelasi antara asupan makronutrien dan kadar vitamin D dikarenakan asupan makanan hanya $10 \%$ mempengaruhi status vitamin $D$ sehingga memerlukan sampel yang lebih banyak untuk melihat kecenderungan korelasi antara kedua variabel.

Asupan vitamin D dari makanan dapat menjadi kontributor penting untuk status vitamin $D^{37}$, tetapi dalam penelitian ini tidak menemukan hubungan antara asupan vitamin D dan kadar serum $25(\mathrm{OH}) \mathrm{D}$. Uji korelasi didasarkan pada koefisien korelasi Pearson yang menunjukkan nilai $p=0,231(p>0,05)$. Penelitian ini berbeda dengan temuan di Jepang yang melaporkan terdapatnya korelasi yang signifikan antara asupan vitamin D makanan dan kadar plasma $25(\mathrm{OH}) \mathrm{D}$ pada 79 orang sehat. Hal ini berarti, asupan makanan dalam jumlah yang cukup vitamin D efektif untuk meningkatkan status vitamin $D^{38}$.

Hasil serupa juga disampaikan dalam studi crosssectional tahun 2006 terhadap 513 anak usia 6-7 tahun, kondisi sehat, tinggal di kota Isfahan $\left(32^{\circ} 39^{\prime} \mathrm{N}\right)$, Iran tanpa riwayat konsumsi suplemen vitamin D. Metode pengumpulan data yang digunakan adalah a 7-day food frequency questionnaire untuk mengetahui asupan harian vitamin D serta kuesioner untuk menentukan jumlah paparan sinar matahari harian anak-anak (menit/hari). Berdasarkan uji regresi, didapatkan hubungan yang signifikan antara paparan sinar matahari ( $\mathrm{min} . \mathrm{cm}^{2} /$ hari) $(b=0,28, p<0,001)$ dan asupan harian vitamin $D(I U / I)(b$
$=0,13, \mathrm{p}=0,002)$ dengan kadar serum $25-\mathrm{OHD}^{39}$. Hasil penelitian lain yang sejenis adalah studi kohort (2010) yang menunjukkan adanya korelasi positif antara asupan vitamin $D$ dengan serum 25(OH)D $(r=0,27 ; p=0,02)$. Studi ini dilakukan untuk mengetahui efek paparan sinar matahari, asupan vitamin D dan pantulan kulit (pigmentasi) terhadap serum 25-hydroxyvitamin D $(25(\mathrm{OH}) \mathrm{D})$ di antara orang dewasa muda California. Subyeknya adalah 72 orang sehat berusia 19-39 tahun serta mengabaikan penggunaan suplemen ${ }^{40}$.

Tiga penelitian di atas berbeda dengan penelitian ini, namun hasil penelitian ini sejalan dengan penelitian cross sectional yang dilaksanakan di Iran. Hasil analisis statistik dalam penelitian tersebut menunjukkan kadar serum $25(\mathrm{OH}) \mathrm{D}$ yang tidak berkorelasi dengan asupan vitamin $D$ makanan $(r=0,22, p=0,349)$. Dalam penelitian tersebut melibatkan lima puluh tiga pasien, usia 8-18 tahun dengan durasi diabetes mellitus tipe 1 kurang dari 8 minggu. Penilaian asupan vitamin $D$ dari makanan menggunakan kuesioner frekuensi makanan (FFQ) sedangkan besarnya paparan sinar matahari diukur menggunakan kuesioner untuk mengukur jumlah waktu yang dihabiskan anak-anak di bawah sinar matahari dan kebiasaan terkait matahari lainnya. Untuk serum 25(OH)D di uji dengan imunoradiometrik menggunakan kit IDS ${ }^{41}$. Jika ditinjau dari segi karakteristik, penelitian di Iran ini memiliki karakteristik yang paling mirip dengan penelitian yang sekarang dilakukan. Sehingga perbedaan hasil yang ditimbulkan dari setiap penelitian dapat disebabkan oleh perbedaan kuesioner atau tabel komposisi makanan yang digunakan untuk memperkirakan asupan makanan. Selain itu, adanya perbedaan sasaran baik etnis, ras, kondisi kesehatan maupun kelompok umur juga turut mempengaruhi hasilnya.

Menurut Sari (2016) terdapat tiga faktor dalam model perubahan gaya hidup yang mempengaruhi kadar vitamin D yaitu paparan sinar matahari, aktifitas fisik dan asupan vitamin D. Suatu penelitian potong lintang menunjukkan adanya korelasi positif yang signifikan antara paparan sinar matahari dengan kadar vitamin $D$ $(p=0,001, r=0,627)^{42}$. Paparan sinar matahari dalam sinar ultra violet (spectrum 280-320 UVB) memberikan peran yang besar dalam membantu sintesis vitamin D3 (3000 IU) di kulit dari 7-dehydrocholesterol $(7-\mathrm{DHC})^{37}$. Selain bersumber dari paparan sinar matahari, vitamin D3 (cholecalsiferol) juga didapatkan dari makanan. Sedangkan vitamin D2 (ergocalciferol) hanya berasal dari tanaman sterol ergosterol ${ }^{43}$. Dalam sebuah referensinya Holick (2018) menjelaskan bahwa 90\% - 95\% kebutuhan vitamin $D$ tubuh berasal dari paparan sinar matahari. Hal ini dapat diartikan, apabila asupan vitamin D dari makanan memenuhi rekomendasi akan memberikan dampak $5-10 \%$ pada proses metabolisme vitamin D menjadi $25(\mathrm{OH}) \mathrm{D}^{44}$ dan sebagian besar ahli sepakat apabila tidak ada paparan sinar matahari maka diperlukan asupan vitamin D dari makanan sebesar $1000 \mathrm{IU}$ vitamin D3 ${ }^{45}$.

Saat pengumpulan data, tidak semua bahan makanan dalam daftar kuesioner merupakan bahan makanan siap konsumsi. Sebagian besar bahan makanan tersebut masih membutuhkan proses pengolahan atau 
pemasakan. Proses pemasakan tingkat rumah tangga menghilangkan $<10 \%$ vitamin $D$ dalam bahan makanan. Cara pemasakan yang dilakukan adalah pemanggangan ikan, perebusan telur dan penggorengan jamur ${ }^{46}$. Lu et al. (2007) menegaskan bahwa kandungan vitamin $D_{2}$ atau $D_{3}$ dalam ikan salmon tergantung tempat hidup dan cara pemeliharaannya ${ }^{45}$. Penjelasan sejenis disampaikan pula atas hasil studi kimia pangan di Denmark yang menyelidiki retensi vitamin D3 dan 25-hydroxyvitamin D3 (25(OH)D) dalam telur, margarin dan roti terhadap berbagai metode memasak yang biasa dilakukan di rumah tangga yaitu merebus, menggoreng dalam wajan dan oven serta memanggang. Hasil yang didapatkan adalah retensi terendah sebesar $39-45 \%$ pada telur dan margarin selama perlakuan panas dalam oven selama 40 menit pada suhu memasak normal sementara menggoreng dan merebus menghasilkan retensi pada $82-84 \%$ dan $86-88 \%$. Untuk roti yang dipanggang memiliki retensi $69 \%{ }^{47}$.

Menurut Lips (2001) asupan kalsium yang rendah menginduksi tingkat PTH serum yang tinggi dan meningkatkan katabolisme $25(\mathrm{OH}) \mathrm{D}$, oleh karena itu konsumsi kalsium yang rendah menyebabkan penurunan $25(\mathrm{OH}) \mathrm{D}^{48}$. Namun, dalam penelitian ini tidak menemukan korelasi antara rata-rata asupan kalsium terhadap kadar vitamin D (25(OH)D). Hasil ini diketahui dari uji hubungan Pearson, koefisien korelasi yang ditunjukkan adalah $\mathrm{p}$ value $=0,244$ atau $\mathrm{p}>0,05$. Hasil penelitian saat ini serupa dengan penelitian cross sectional oleh Ataie-Jafari et al (2012) di Iran dengan karakteristik responden dan metode pengumpulan data asupan kalsium harian yang mirip. Penelitian ini menyatakan bahwa kadar serum 25(OH)D tidak berkorelasi dengan asupan kalsium makanan $(p=0,091)$

Namun, hasil berbeda dengan penelitian kohort di Italia. Hasil penelitian tersebut menunjukkan adanya korelasi positif yang signifikan antara asupan kalsium terhadap kadar 25(OH)D dengan nilai $p=0,001(p<0,05)$. Subyek yang dilibatkan adalah 850 wanita pascamenopause, ras Kaukasia yang berusia $60-80$ tahun dengan risiko osteoporosis, diet rendah kalsium atau tidak toleran terhadap produk susu dan sama sekali tidak mengonsumsi suplemen kalsium oral. Masa perekrutan dimulai pada 15 Februari 2000 dan berakhir pada 15 Maret 2000. Serum 25(OH)D diukur dengan radioimmunoassay (RIA) menggunakan kit komersial (batas deteksi 1,5 ng / ml; DiaSorin, Italia); serum PTH 184 utuh diukur menggunakan metode imunoradiometrik (DiaSorin, Italia) dengan sensitivitas $0,7 \mathrm{pg} / \mathrm{ml}$. Asupan kalsium dinilai oleh dokter menggunakan kuesioner multiitem termasuk daftar besar makanan ${ }^{49}$.Perbedaan hasil penelitian dapat terjadi akibat perbedaan responden dan metode yang dilakukan. Penelitian yang dilakukan sekarang ini tidak memperhitungkan tingkat serum PTH responden yang merupakan indikator langsung pada ketersediaan kalsium dalam tubuh. Metabolisme kalsium merupakan konversi 25(OH)D dalam ginjal oleh 25hydroxyvitamin D-1 $\alpha$-hydroxylase (1-OHase) menjadi 1,25-dihydroxyvitamin $\mathrm{D}\left[1,25(\mathrm{OH})_{2} \mathrm{D}\right]$. Kadar kalsium, fosfor dan fibroblast growth factor 23 (FGF 23) dapat meningkatkan atau menurunkan sintesis dan sekresi hormon paratiroid (PTH) ${ }^{44}$

Dalam penelitian ini masih terdapat keterbatasan dari berbagai faktor yang mempengaruhi diantaranya paparan sinar matahari, status gizi, intake makanan dan kadar vitamin D hanya dilakukan dalam satu kali pengukuran, diperlukan pengukuran berulang untuk mengetahui hubungan lebih jauh antar variabel penelitian; pengukuran paparan sinar matahari hanya menggunakan kuisioner, diperlukan pengukuran menggunakan peralatan UV Dosimeter untuk mendapatkan hasil paparan sinar matahari responden yang lebih akurat; pengukuran status gizi hanya dilakukan berdasarkan indeks massa tubuh, diperlukan pengukuran dengan metode BIA untuk mengetahui status gizi berdasarkan komposisi tubuh (Lean and fat body mass) dan kaitannya dengan bioavailabilitas vitamin D; selain itu penelitian hanya melihat obesitas berdasarkan Indeks Massa Tubuh, perlu juga dilakulan penelitian tentang tingkat aktifitas pada anak dan remaja penderita Diabetes Tipe 1 karena obesitas berkaitan dengan kurangnya aktifitas fisik; dan juga penelitian ini hanya dilakukan pada anak dan remaja Diabetes Tipe 1 dan tidak ada kontrol anak sehat.

\section{KESIMPULAN}

Dari hasil penelitian ini dapat disimpulkan bahwa terdapat korelasi yang bermakna dengan arah positif dan kekuatan hubungan yang kuat antara paparan sinar matahari dengan kadar vitamin $D$ pada anak dan remaja penderita Diabetes Mellitus Tipe 1 di Poli rawat jalan RS dr Saiful Anwar Malang dan tidak terdapat korelasi yang signifikan antara status gizi dan asupan makan dengan kadar vitamin $D$ pada anak dan remaja penderita Diabetes Mellitus Tipe 1 di Poli rawat jalan RS dr Saiful Anwar Malang. Perlu dilakukan skrining defisiensi vitamin $\mathrm{D}$ secara dini dan penelitian eksperimen tentang pengaruh paparan sinar matahari dalam meningkatkan kadar Vitamin D responden. Selain itu juga dapat dilakukan penelitian status gizi berupa komposisi tubuh dengan metode DEXA melihat komposisi tubuh sehingga dapat dilihat lebih jauh hubungan lemak tubuh dengan kadar vitamin $\mathrm{D}$.

\section{ACKNOWLEDGEMENT}

Peneliti mengucapkan terima kasih kepada IKADAR (Ikatan Keluarga Penyandang Diabetes Anak dan Remaja) Kota Malang dan seluruh enumerator yang terlibat dalam kegiatan penelitian ini.

\section{REFERENS|}

1. Fazeli Farsani, S. et al. Increasing trends in the incidence and prevalence rates of type 1 diabetes among children and adolescents in the Netherlands. Pediatr. Diabetes 17, 44-52 (2016).

2. Piemonte, L. IDF Diabetes Atlas 8th Edition 2017 Global Fact Sheet. (2018). Available at: https://idf.org/52-about-diabetes.html. (Accessed: 5th January 2019)

3. B, T. et al. UKK Endokrinologi Anak dan Remaja: Konsensus Nasional Pengelolaan Diabetes Mellitus 
Tipe 1 pada Anak dan Remaja. (Badan Penerbit IDAI, 2015).

4. Feng, R. et al. Lower Serum $25(\mathrm{OH})$ D concentrations in type 1 diabetes: A meta-analysis. Diabetes Res. Clin. Pract. 108, 8-12 (2015).

5. Alghamdi, A. High Prevalence of Vitamin D Deficiency Among Saudi Children And Adolescents With Type 1 Diabetes In Albaha Region, Saudi Arabia. IOSR J. Pharm. Biol. Sci. 12, 5-10 (2017).

6. Kaur, H. et al. Vitamin D Deficiency Is Associated With Retinopathy in Children and Adolescents With Type 1 Diabetes. Diabetes Care 34, 1400-1402 (2011).

7. de Boer, I. H. et al. Circulating Vitamin D Metabolites and Kidney Disease in Type 1 Diabetes. J. Clin. Endocrinol. Metab. 97, 4780-4788 (2012).

8. Mahan, L. K. \& Raymond, J. L. Krause's Food \& the Nutrition Care Process. (Elsevier, 2016).

9. Holick, M. F. Photobiology of vitamin D: Biochemistry, Physiology and Diagnostics, Fourth Edition. (Elsevier, 2018).

10. Al-Othman, A. et al. Effect of physical activity and sun exposure on vitamin $D$ status of Saudi children and adolescents. BMC Pediatr. 12, 92 (2012).

11. Mohr, S., Garland, C., Gorham, E. \& Garland, F. The association between ultraviolet $B$ irradiance, vitamin $D$ status and incidence rates of Type 1 diabetes in 51 regions worldwide. Diabetologia 51, 1391-1398 (2008).

12. Wirjomidjojo, S. \& Swarinoto, Y. S. Iklim kawasan Indonesia: dari aspek dinamik-sinoptik. ([Pusat Penelitian dan Pengembangan], Badan Meteorologi Klimatologi dan Geofisika, 2010).

13. Tzotzas, T. et al. Rising Serum 25-Hydroxy-Vitamin D Levels after Weight Loss in Obese Women Correlate with Improvement in Insulin Resistance. J. Clin. Endocrinol. Metab. 95, 4251-4257 (2010).

14. Earthman, C., Beckman, L., Masodkar, K. \& Sibley, S. The link between obesity and low circulating 25hydroxyvitamin D concentrations: Considerations and implications. Int J Obes 36, 387-396 (2011).

15. Kumar, J., Muntner, P., Kaskel, F. J., Hailpern, S. M. \& Melamed, M. L. Prevalence and associations of 25-hydroxyvitamin $D$ deficiency in US children: NHANES 2001-2004. Pediatrics 124, e362-e370 (2009).

16. Pereira-Santos, M., Costa, P. R. de F., Assis, A. M. O. de, Santos, C. A. de S. T. \& Santos, D. B. dos. Obesity and vitamin $D$ deficiency: a systematic review and meta-analysis. Obes. Rev. 16, 341-349 (2015).

17. Dahlan, M. S. Statistik untuk kedokteran dan kesehatan. (Penerbit Salemba).

18. Hanwell, H. E. C. et al. Sun exposure questionnaire predicts circulating 25-hydroxyvitamin D concentrations in Caucasian hospital workers in southern Italy. J. Steroid Biochem. Mol. Biol. 121, 334-337 (2010).

19. Handayani, D. et al. Nutition Care Process. (Graha Ilmu, 2015).

20. Kemenkes-RI. Angka Kecukupan Gizi (AKG) 2013. (Litbang Kemenkes, 2013).
21. Atkinson, M. A., Eisenbarth, G. S. \& Michels, A. W. Type 1 diabetes. Lancet 383, 69-82 (2014).

22. Diaz-Valencia, P. A., Bougnères, P. \& Valleron, A.-J. Global epidemiology of type 1 diabetes in young adults and adults: a systematic review. BMC Public Health 15, 255 (2015).

23. Pereira, D. A., Costa, N. M. da S. C., Sousa, A. L. L., Jardim, P. C. B. V. \& Zanini, C. R. de O. The effect of educational intervention on the disease knowledge of diabetes mellitus patients. Rev. Lat. Am. Enfermagem 20, 478-485 (2012).

24. Dix, C. F. et al. Association of sun exposure, skin colour and body mass index with vitamin $D$ status in individuals who are morbidly obese. Nutrients $\mathbf{9}$, 1094 (2017).

25. Wacker, M. \& Holick, M. F. Sunlight and Vitamin D: A global perspective for health. Dermatoendocrinol. 5, 51-108 (2013).

26. Linos, E. et al. Sun protective behaviors and vitamin D levels in the US population: NHANES 2003-2006. Cancer Causes Control 23, 133-140 (2012).

27. Holick, M. The D-Lightful Vitamin D for Child Health. JPEN. J. Parenter. Enteral Nutr. 36, 9S-19S (2011).

28. Meena, P. et al. Sunlight exposure and vitamin D status in breastfed infants. Indian Pediatr. 54, 105111 (2017).

29. Saki, F., Omrani, G. R., Pouralborz, Y. \& Dabbaghmanesh, M. H. Vitamin D deficiency and the associated factors in children with type 1 diabetes mellitus in southern Iran. Int. J. Diabetes Dev. Ctries. 37, 78-84 (2017).

30. Hassan, M. \& Alashmawy, A. Vitamin D Status in Egyptian Children and Adolescents with Type 1 Diabetes Mellitus. J. Diabetes Metab. 07, 1-4 (2015).

31. Mosso, C., Halabi, V., Ortiz, T. \& Hodgson, M. I. Dietary intake, body composition, and physical activity among young patients with type 1 diabetes mellitus. J. Pediatr. Endocrinol. Metab. 28, 895-902 (2015).

32. Vimaleswaran, K. S. et al. Causal relationship between obesity and vitamin $D$ status: bidirectional Mendelian randomization analysis of multiple cohorts. PLoS Med 10, e1001383 (2013).

33. Savastano, S. et al. Low vitamin D status and obesity: Role of nutritionist. Rev. Endocr. Metab. Disord. 18, 215-225 (2017).

34. Mazahery, H. \& Von Hurst, P. R. Factors affecting 25-hydroxyvitamin $D$ concentration in response to vitamin D supplementation. Nutrients $7,5111-5142$ (2015).

35. Ranjan, A. et al. Low-carbohydrate diet impairs the effect of glucagon in the treatment of insulininduced mild hypoglycemia: a randomized crossover study. Diabetes Care 40, 132-135 (2017).

36. Smart, C. E. et al. ISPAD Clinical Practice Consensus Guidelines 2018: Nutritional management in children and adolescents with diabetes. Pediatr. Diabetes 19, 136-154 (2018).

37. Palermo, N. E. \& Holick, M. F. Role of Vitamin D in 
the Pathogenesis of Diabetes. (Springer, 2017).

38. Takeuchi, A., Okano, T., Ishida, Y. \& Kobayashi, T. Effects of dietary vitamin $D$ intake on plasma levels of parathyroid hormone and vitamin D metabolites in healthy Japanese. Miner. Electrolyte Metab. 21, 217-222 (1995).

39. Ardestani, P. M. et al. Vitamin D status of 6- to 7year-old children living in Isfahan, Iran. Endokrynol. Pol. 61, 377-382 (2010).

40. Hall, L. M. et al. Vitamin D intake needed to maintain target serum 25-hydroxyvitamin D concentrations in participants with low sun exposure and dark skin pigmentation is substantially higher than current recommendations. J. Nutr. 140, 542-550 (2010).

41. Ataie-Jafari, A. et al. Vitamin D status and associated factors in recent-onset type 1 diabetic children in Iran. J. Diabetes Metab. Disord. 11, 12 (2012).

42. Sari, D. K. Buku Referensi Nutrien Vitamin D dan Mineral Kalsium. (USU press, 2016).

43. Bikle, D. D. Vitamin D metabolism, mechanism of action, and clinical applications. Chem. Biol. 21,
319-329 (2014)

44. Holick, M. F. Photobiology of Vitamin D. 1, 45-55 (2018).

45. Lu, Z. et al. An evaluation of the vitamin D 3 content in fish: Is the vitamin $D$ content adequate to satisfy the dietary requirement for vitamin D? J. Steroid Biochem. Mol. Biol. 103, 642-644 (2007).

46. Mattila, P., Ronkainen, R., Lehikoinen, K. \& Piironen, V. Effect of household cooking on the vitamin $D$ content in fish, eggs, and wild mushrooms. J. Food Compos. Anal. 12, 153-160 (1999).

47. Jakobsen, J. \& Knuthsen, P. Stability of vitamin D in foodstuffs during cooking. Food Chem. 148, 170175 (2014).

48. Lips, P. Vitamin D deficiency and secondary hyperparathyroidism in the elderly: consequences for bone loss and fractures and therapeutic implications. Endocr. Rev. 22, 477-501 (2001).

49. Adami, S., Viapiana, O., Gatti, D., Idolazzi, L. \& Rossini, M. Relationship between serum parathyroid hormone, vitamin D sufficiency, age, and calcium intake. Bone 42, 267-270 (200). 